\title{
Propagation Techniques and Grafting Modify the Morphological Traits of Roots and Biomass Allocation in Avocado Trees
}

\author{
Claudia Fassio ${ }^{1,2,3}$, Ricardo Cautin ${ }^{1}$, Alonso Pérez-Donoso ${ }^{2}$, \\ Claudia Bonomelli ${ }^{2}$, and Mónica Castro ${ }^{1}$
}

AdDitional INDEX wORDs. clonal propagation, graft, Persea americana, order roots, root-to-shoot ratio

SUMMARY. Root morphological traits and biomass allocation were studied in 2 -year-old 'Duke 7 ' avocado ( Persea americana) trees propagated using seedling and clonal techniques. The plants either were or were not grafted with the scion 'Hass'. Whole tree excavation 1 year after planting revealed that the propagation technique affected the root growth angle of the main roots (third order roots), the root length density (defined as the total length of roots per volume of soil), and the number of first and second order roots present. The root system of clonal trees showed a typical morphology of rooted cuttings, with a crown of roots originating from a relatively short stem, resulting in a shallow root system. Clonal trees, compared with seedlings, produced main framework roots with shallower angles and more fine roots (first and second order roots) that increased the root length density (defined as the total length of roots per volume of soil). Nongrafted seedlings exhibited a main taproot and lateral roots with narrow angles that penetrated deeper into the soil and increased the aboveground biomass but had a lower root-to-shoot ratio than nongrafted clonal trees. The grafting of both clonal and seedling trees resulted in similar root architecture and revealed that grafting significantly decreased the soil volume explored and the shoot and root biomass. Although both root systems were shallow, grafted clonal trees had a higher root-to-shoot ratio than grafted seedlings. In this study, a distinct class of roots with large diameter and unbranched growth was more abundant in the root systems of clonal trees. These types of roots (previously undescribed in avocado trees), called pioneer roots, may enhance soil exploration in clonal trees.

L

ong-term research on avocado roots has not been performed in detail, mainly due to the difficulty and time required for these types of studies. However, at present, the use of genotypes with efficient root systems appears to be a key crop trait for sustainable intensification of agricultural production; consequently, research in this area has become more important (Gewin, 2010; Gregory et al., 2013).

The results of recent studies on the morphological characteristics of root systems have provided insight into the relationship between root architecture and the resulting increased efficiency in the use of important resources, such as water and nutrients, and improved productivity of cultivated crop species. For

${ }^{1}$ Facultad de Agronomía, Pontificia Universidad Católica de Valparaíso, Casilla 4-D Quillota, Chile

${ }^{2}$ Departmento de Fruticultura y Enología, Facultad de Agronomía e Ingeniería Forestal, Pontificia Universidad Católica de Chile, Casilla 306-22 Santiago, Chile

${ }^{3}$ Corresponding author. E-mail: frutales@ucv.cl. example, in soils with low phosphorus levels, the genotypes of common bean (Phaseolus vulgaris), which have shallow root systems, exhibit better development and productivity than genotypes with deeper rooting architecture (Henry et al., 2010; Ho et al., 2004; Rubio et al., 2001). The importance of root architecture for plant productivity relies on the fact that soil resources, such as water and nutrients, are unevenly distributed or are subjected to localized depletion. Thus, knowledge of the root system of a plant species is essential to exploit these resources (López-Bucio et al., 2003; Lynch, 1995).

The propagation technique used has been shown to influence the root architecture of crops. Recent studies of jatropha (Jatropha curcas) by Severino et al. (2011) indicated that seedling propagation generated a more vigorous root system than propagation through stem cuttings. In peach (Prunus persica) trees, a comparison between the air layering method and traditional tree propagation from seeds demonstrated that the rootstock genotype and the propagation method affected productivity and peach fruit quality (Picolotto et al., 2010).

Limited data are available regarding the effects of grafting on root system development in grafted commercial fruit tree crops. Firth et al. (2003) documented a significant effect of grafting on the root architecture of macadamia (Macadamia tetraphylla) trees. Nongrafted trees had long taproots $(120 \mathrm{~cm})$ and grafted trees exhibited short taproots $(40 \mathrm{~cm})$, with most of the fibrous root system located near the soil surface.

In commercial avocado orchards, both seedling and clonally propagated rootstocks are used. Commercial nursery production has primarily involved the use of seedling rootstocks, but due to the great heterozygosity of avocado trees, vegetative propagation techniques have been developed and used to improve the uniform tolerance to poor soil conditions and increase productivity (Schaffer et al., 2013). Clonally propagated rootstocks are the result of grafting the desired rootstock onto a seedling nursery tree, etiolating and rooting the desired rootstock, and then grafting the desired scion variety onto the rooted etiolated shoot (Frolich and Platt, 1972). Due to the importance of root architecture

\begin{tabular}{llll}
\hline $\begin{array}{l}\text { Units } \\
\text { To convert U.S. to SI, } \\
\text { multiply by }\end{array}$ & U.S. unit & SI unit & $\begin{array}{l}\text { To convert SI to U.S., } \\
\text { multiply by }\end{array}$ \\
\hline 0.3048 & $\mathrm{ft}$ & $\mathrm{m}$ & 3.2808 \\
0.0283 & $\mathrm{ft}^{3}$ & $\mathrm{~m}^{3}$ & 35.3147 \\
3.7854 & gal & $\mathrm{L}$ & 0.2642 \\
2.54 & inch(es) & $\mathrm{cm}$ & 0.3937 \\
25.4 & inch $(\mathrm{es})$ & $\mathrm{mm}^{3}$ & 0.0394 \\
16.3871 & inch & $\mathrm{cm}^{3}$ & 0.0610 \\
28.3495 & $\mathrm{Oz}$ & $\mathrm{g}$ & 0.0353 \\
$\left({ }^{\circ} \mathrm{F}-32\right) \div 1.8$ & ${ }^{\circ} \mathrm{F}$ & ${ }^{\circ} \mathrm{C}$ & $\left({ }^{\circ} \mathrm{C} \times 1.8\right)+32$
\end{tabular}


to tree physiology and productivity, the goal of this research was to quantify the effects of this unique clonal propagation technique and grafting on avocado root architecture and biomass allocation.

\section{Material and methods}

Site and Plant material. The study site was located at the experimental station of Pontificia Catholic University of Valparaíso, in the Province of Quillota (lat. $32^{\circ} 50^{\prime} \mathrm{S}$, long. $\left.71^{\circ} 13^{\prime} \mathrm{W}\right)$, in the Valparaíso Region of Chile. The soil type was loamy clay of lacustrine origin and moderate depth. Mother trees were maintained under commercial management, to regulate fertility, irrigation, and pest control, in the avocado germplasm bank located at the experimental station. The budwoods used from these trees ('Duke 7' and 'Hass') were hardwoods $(10 \mathrm{~cm}$ in length and $0.5 \mathrm{~cm}$ in diameter).

The seeds were collected from uniform, physiologically mature fruits. The budwoods and 'Duke 7' seeds were collected in the late winter from the same healthy and vigorous 'Duke 7' mother tree (10 years old). The plants were propagated in a shaded greenhouse. The average greenhouse temperature ranged between 25 and $30{ }^{\circ} \mathrm{C}$, the relative humidity ranged from $50 \%$ to $100 \%$, and the average photosynthetic photon flux at midday was between 200 and $250 \mu \mathrm{mol} \cdot \mathrm{m}^{-2} \cdot \mathrm{s}^{-1}$.

Propagation treatments. Clonal propagation was performed using the Brokaw method (Brokaw, 1987) based on the double grafting technique of Frolich and Platt (1972). Vigorous seedlings produced from 'Esther' seeds were used as a temporary nurse root system. A 1 -month-old seedling was apical wedge grafted with 'Duke 7' budwood (clone). A single stronger bud was retained when the 'Duke 7' graft began to grow, and when it reached $2 \mathrm{~cm}$, the plants were transferred to a darkened chamber with the temperature maintained at 25 to $30^{\circ} \mathrm{C}$. When the etiolated shoot reached a height of 8 to $10 \mathrm{~cm}$, it was removed from the darkness and treated with a 1600-ppm rooting solution of indole-3-butyric acid (Sigma-Aldrich, St. Louis, MO). A metal ring was clamped near the base of the shoot and 'Hass' was grafted
$5 \mathrm{~d}$ after the rooting treatment. A sphagnum peat-based substrate (Sunshine Mix 1; Sun Gro Horticulture, Bellevue, WA) was used for both propagation techniques. The nutrients were incorporated into a substrate with $15 \mathrm{~N}-4.1 \mathrm{P}-10 \mathrm{~K}$ controlledrelease fertilizer (Osmocote Plus, 8-9 month Southern release; ScottsSierra Horticultural Products, Marysville, $\mathrm{OH}$ ).

For seedling propagation, the 'Duke 7' seeds were placed in 1-L polyethylene bags, and when the trees had a stem diameter of $5 \mathrm{~mm}$ ( 1 -month old $)$, the seedlings were apical wedge grafted with 'Hass' collected from the same healthy and vigorous 5 -year-old mother tree used for grafting clonal trees. The grafted plants (seedling and clonal) were arranged in the same area inside the greenhouse.

Grafting treatment. Grafting was performed with $5-\mathrm{mm}$ stem diameter (softwood) clonal and seedling rootstocks. In the apical wedge graft, a single long cut $(2.5$ to $5 \mathrm{~cm})$ was made through the center of the rootstock, and then the base of the scion was cut twice to form a V shape, which was then fit onto the rootstock cut (Hartmann et al., 2010). The control treatment was not grafted.

The clonal trees were grown in a greenhouse for 7 months, whereas the seedlings were grown in a greenhouse for 3 months. This difference was due to clonal rootstocks requiring more time to reach a stem diameter that was a suitable size for grafting. The plants were watered with tap water when $30 \%$ of the seedlings were slightly wilted.

TREATMENT AND EXPERIMENTAL DESIGN. Nine 1-year-old trees of each combination of rootstocks, nongrafted clonal 'Duke 7', 'Hass' grafted onto clonal 'Duke 7', nongrafted seedling 'Duke 7', and 'Hass' grafted onto seedling 'Duke 7' were planted in the field on 15 Mar. 2012 at a spacing of $3 \times 3 \mathrm{~m}$. The trees were arranged in a randomized complete block design with nine replications. The site variability was used as a blocking factor. Each block included one tree for each propagation-grafting treatment combination (four trees per block). During the experiment, the plants were irrigated and fertilized using Microjet $\left(20 \mathrm{~L} \cdot \mathrm{h}^{-1}\right)$ sprinklers (SuperNet; Netafim USA,
Fresno, CA) with a Hoagland and Arnon nutrient solution (Hoagland and Arnon, 1938), modified according to Maas and Poss (1989) to provide optimal conditions of nutrient availability.

This modified solution consisted of $46.3 \mathrm{~mm}$ boric acid, $9.10 \mathrm{~mm}$ manganese chloride tetrahydrate, $0.77 \mathrm{~mm}$ zinc sulfate heptahydrate, $0.32 \mathrm{~mm}$ copper sulfate pentahydrate, $0.12 \mathrm{~mm}$ disodium molybdenum tetraoxide, $1 \mathrm{~mm}$ ammonium dihydrogen phosphate, $6.0 \mathrm{~mm}$ potassium nitrate, $5.8 \mathrm{~mm}$ calcium nitrate tetrahydrate, $2.0 \mathrm{~mm}$ magnesium sulfate heptahydrate, and $0.4 \mathrm{~mm}$ iron-ethylenediaminetetraacetic acid. The soil water content was measured with a frequency domain reflectometry probe (Diviner 2000; Sentek Sensor Technologies, Adelaide, Australia) to determine the timing and amount of irrigation to maintain the soil water content at a value similar to field capacity $(25 \mathrm{~mm}$ at $30 \mathrm{~cm}$ of soil depth).

ROOT SYSTEM MORPHOLOGY AND BIOMASs. One year after planting, the trees were excavated with the entire root system intact using the method described by Atkinson (2000). Soil blocks $(1 \times 1 \times 1 \mathrm{~m})$ were excavated at a distance of $0.5 \mathrm{~m}$ from each selected tree. Each plant was harvested, and the entire root system was placed in 100-L containers and soaked in tap water for $12 \mathrm{~h}$. The vertical depth of roots and the lateral root extension were estimated by measuring the maximum distance from the roots to the trunk base with a steel measuring tape with an accuracy of $1 \mathrm{~mm}$. The root diameter was measured at quarter points across the root length using a slide gauge with an accuracy of $0.02 \mathrm{~mm}$. The growth angles between the main roots and the horizontal plane in each tree were measured with a large protractor. The root components were pooled into groups according to their hierarchical order (first, second, and third) using the approach developed by Valenzuela-Estrada et al. (2008). The number, diameter, and length of the first and second order roots were recorded and analyzed with WinRhizo Pro version $2007 \mathrm{~d}$ software (Regent Instruments, QC, Canada). The third order roots were measured with a digital caliper (Absolute Digimatic; Mitutoyo, Kawasaki, Japan). The plants 
were separated into stems, leaves, and roots, and the tissues were dried in a forced-air oven at $70{ }^{\circ} \mathrm{C}$ for $72 \mathrm{~h}$ for biomass determination. The shoot dry weight was equal to the sum of the aerial vegetative plant parts (leaves + stems). The root-to-shoot ratio was calculated by dividing the root dry weight by the sum of the leaf and stem dry weights.

Statistical anAlysis. The data were analyzed using two-way analysis of variance, and the mean separation was performed with Fisher's least significant difference test using SPSS software (version 17.0.1; IBM Corp., Armonk, NY) to test the main effects of the treatments and their interactions.

\section{Results}

The clonal root systems revealed a typical morphology of rooted cuttings. They did not have a central taproot. The root system consisted of a crown of main framework roots, with wider angles originating from a relatively short stem, resulting in a shallow root system. The main framework roots (third order roots) branched into secondary branches (second order roots) and then into lateral short roots (first order) with different lengths and thicknesses (Fig. 1). A different type of root was mainly found in clonal trees (grafted and nongrafted). These roots originated from the stem or third order roots and had a large diameter (similar to third order roots) without branching similar to the pioneer roots reported in other species. Grafting generated a similar root structure in clonal trees; however, the grafted trees exhibited a significant decrease in the amount of soil volume explored and the shoot and root biomass (Tables 1 and 2 ).

The nongrafted seedling root systems exhibited a main taproot and lateral roots (third order) that showed narrow angles and penetrated deeper into the soil with a significantly greater vertical depth of the root frame than the other combinations (Table 1). The seedling root system consisted of a long main root (taproot) with lateral roots (third order) branching into secondary branches (second order roots), then into lateral short roots (first order), with similar length and thickness to the clonal root system (Fig. 1). In the seedling trees, grafting changed the root

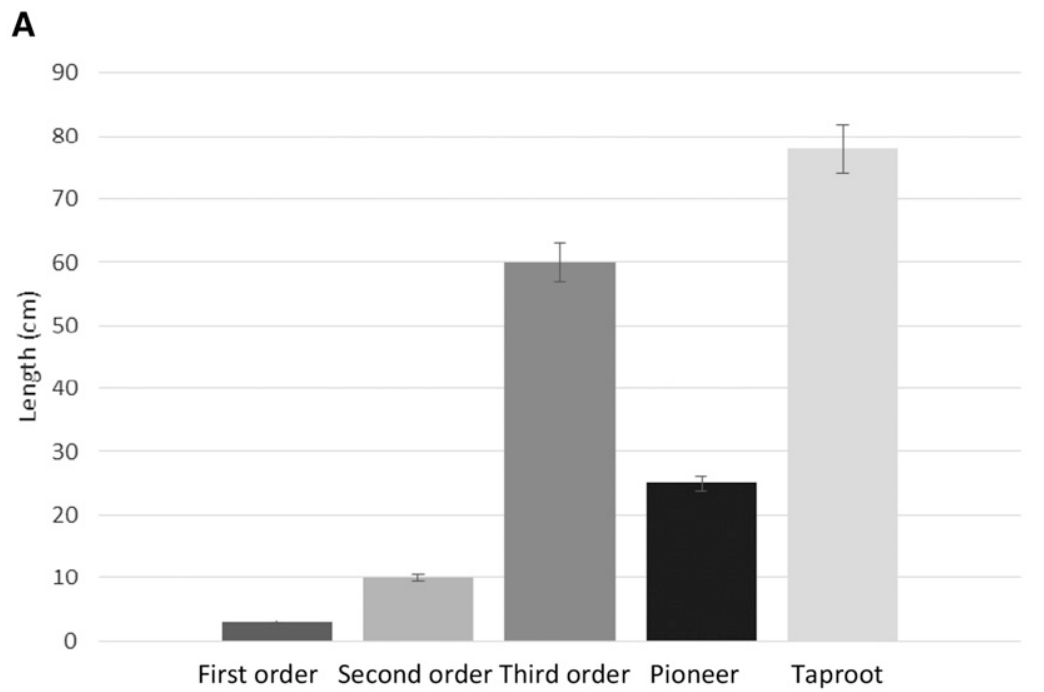

B

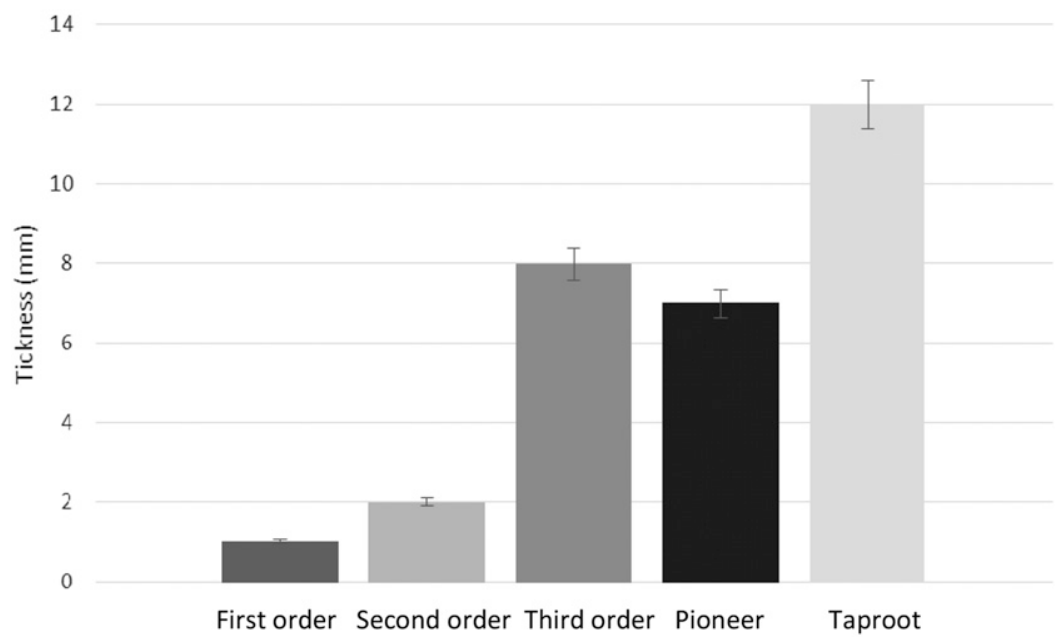

Fig. 1. Root length (A) and thickness (B) according to the root order of 2-year-old 'Duke 7' avocado trees grown in Quillota, Chile. The values represent the means \pm SE of nine trees; $1 \mathrm{~cm}=0.3937 \mathrm{inch}, 1 \mathrm{~mm}=0.0394 \mathrm{inch}$.

architecture, which was similar to the structure of the clonal, grafted trees. Although both root systems were shallow, the grafted clonal trees had a higher root-to-shoot ratio than the grafted seedlings. Additionally, in seedling trees, grafting decreased the shoot and root biomass (Table 2).

Clonal trees, compared with seedlings, had framework roots with shallower angles and a higher number of fine roots (first and second order roots), which increased the root length density (Tables 1 and 3).

\section{Discussion}

The propagation technique affected the root growth angle of the main roots (third order roots), root length density, and the number of first and second order roots present. Our results are consistent with previous reports of this effect in other species (Asaah et al., 2012; Charles-Dominique et al., 2009; Piccotino et al., 1992; Severino et al., 2011). In avocado clonal rootstocks, the main roots of etiolated stems were positioned at right angles to the main axis. In seedling rootstocks, the main roots consisted of branches of taproots with narrow angles. The wider branch angles in the clonal trees compared with the seedling trees were likely caused by the etiolation required for adventitious root formation from the stem. Several studies have provided evidence that continuous darkness produces sucrose starvation and thus the disappearance of starch grains in the etiolated stem, 
Table 1. The effect of the propagation technique and grafting on the vertical depth of the root frame, soil volume explored, root length density, and main root growth angle of 2 -year-old 'Duke 7 ' avocado trees grown in Quillota, Chile ( $\mathbf{n}=9$ ).

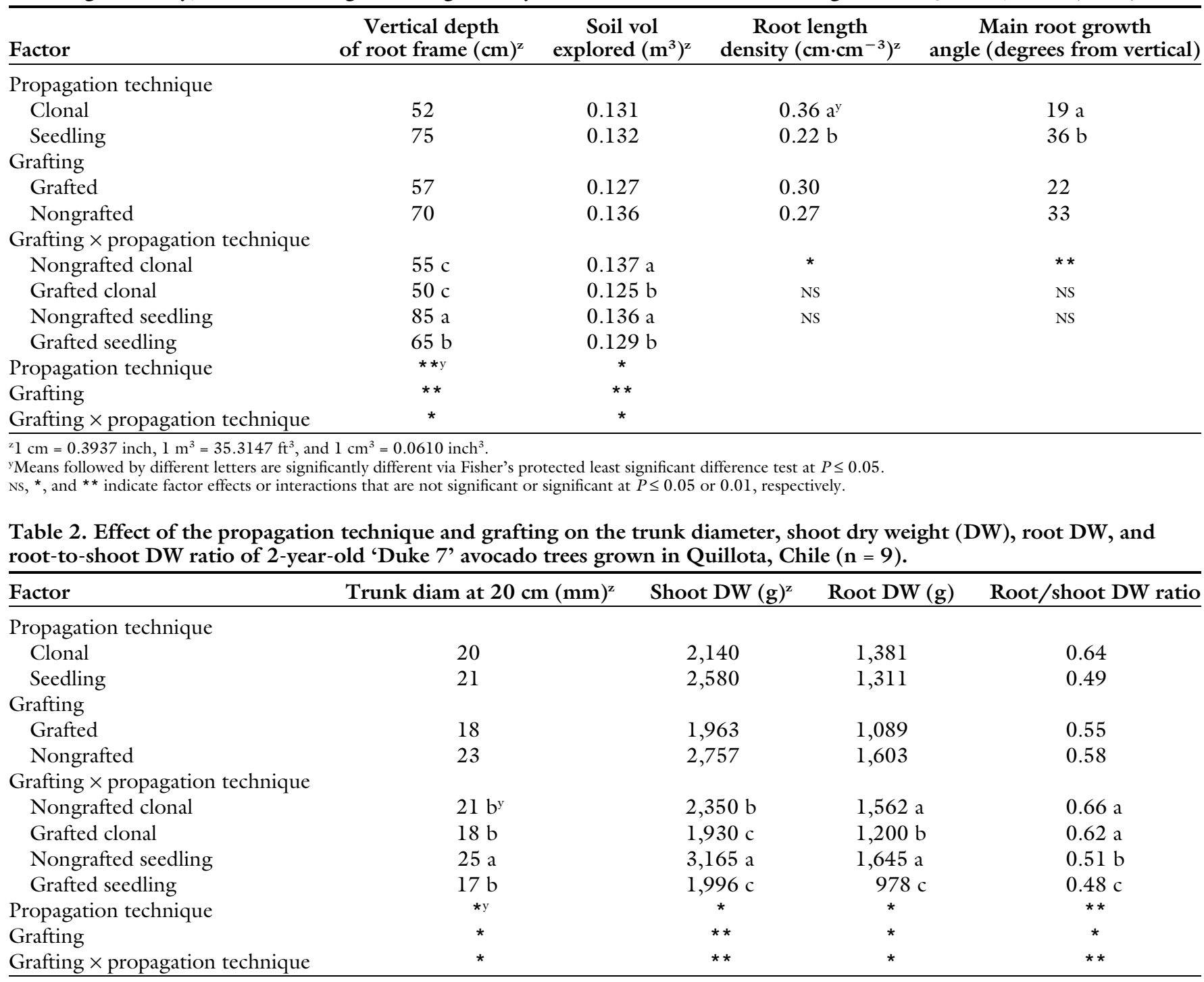

${ }^{\mathrm{z}} 1 \mathrm{~cm}=0.3937$ inch, $1 \mathrm{~mm}=0.0394$ inch, and $\mathrm{l} \mathrm{g}=0.0353 \mathrm{oz}$.

${ }^{y}$ Means followed by different letters are significantly different via Fisher's protected least significant difference test at $P \leq 0.05$.

*and ${ }^{* *}$ represent factor effects or interactions that are significant at $P \leq 0.05$ or 0.01 , respectively.

resulting in a small amount of amyloplast particles in the root cap cells of the adventitious roots (Vinterhalter and Vinterhalter, 1999; Yamashita et al., 1997).

The architecture of a root system is defined by the root angle at an early growth stage (Sanguineti et al., 2007 ). The position and number of lateral roots that appear along the principal root, as well as the angle that they form, determine the soil exploration capacity of a root system. In many species, narrow angles tend to extract more water at a depth below the plant, whereas wide angles tend to increase lateral water extraction (Manschadi et al., 2006). The root angle, diameter, and root elasticity also define the root system's mechanical resistance to wind and other forces acting upon the root stem base. The presence of a taproot with horizontal laterals plays an important role in anchoring young trees. According to Khuder et al. (2007), in maritime pine trees (Pinus pinaster), if the taproot is missing or smaller in size, then the anchorage is less efficient, and permanent stem deflection or toppling could occur during a storm.

The characteristic ability of clonal root systems (grafted and nongrafted) to produce more fine roots (second and first order roots) and greater root length density than seedling rootstocks that was observed in the present study is especially important for the uptake of water and essential nutrients (Gordon and Jackson, 2000; Jackson et al., 1997; Nepstad et al., 1994; Pregitzer, 2002). High fine root densities increase the hydraulic contact between plants and soil and the water uptake rate, thereby contributing to increased potential transpiration rates (Nepstad et al., 1994; Williams et al., 1998) and embolism repair (Zeppel et al., 2004). However, in clonal trees, the absence of a taproot makes the presence of a well-developed root crown crucial (with radial main roots extending outward and downward from the crown) and essential for tree stability. 
Table 3. Effect of propagation technique and grafting on the numbers of first, second, and third order pioneer roots among 2-year-old 'Duke 7' avocado trees grown in Quillota, Chile.

\begin{tabular}{|c|c|c|c|c|}
\hline Factor & $\begin{array}{l}\text { First order } \\
\text { roots }(\text { no. })^{\mathrm{z}}\end{array}$ & $\begin{array}{l}\text { Second order } \\
\text { roots }(\text { no. })^{\mathrm{z}}\end{array}$ & $\begin{array}{l}\text { Third order } \\
\text { roots }(\text { no. })^{\mathrm{z}}\end{array}$ & $\begin{array}{r}\text { Pioneer } \\
\text { roots (no. }\end{array}$ \\
\hline \multicolumn{5}{|l|}{ Propagation technique } \\
\hline Clonal & $15 \mathrm{a}^{\mathrm{y}}$ & 8 a & 7 & $4 \mathrm{a}$ \\
\hline Seedling & $9 \mathrm{~b}$ & $5 \mathrm{~b}$ & 6 & $1 \mathrm{~b}$ \\
\hline \multicolumn{5}{|l|}{ Grafting } \\
\hline Grafted & 9 & 7 & 5 & 2 \\
\hline Nongrafted & 10 & 8 & 6 & 3 \\
\hline Propagation technique & $* * y$ & * & NS & ** \\
\hline Grafting & NS & NS & NS & NS \\
\hline $\begin{array}{l}\text { Grafting } \times \text { propagation } \\
\text { technique }\end{array}$ & NS & NS & NS & NS \\
\hline
\end{tabular}

${ }^{\mathrm{z}}$ For first order and pioneer roots, $\mathrm{n}=9$; for second and third order roots, $\mathrm{n}=30$.

${ }^{y}$ Means followed by different letters are significantly different via Fisher's protected least significant difference test at $P \leq 0.05$

NS, *, and ** represent factor effects or interactions that are not significant or significant at $P \leq 0.05$ or 0.01 , respectively.

The presence of pioneer roots mainly in the clonal avocado root system, as observed in the present study, was a result of the propagation technique used. The presence of pioneer roots in clonal propagated avocado trees has not been previously reported. Pioneer roots have been described in many other species and are considered important for vertical and horizontal soil exploration (Kolesnikov, 1971; Lyford, 1980; Sutton and Tinus, 1983; Wilcox, 1964) and tolerance to pathogen colonization (Emmett et al., 2014). According to Polverigiani et al. (2011), these roots have a coarse diameter, show fast growth, have an extended length at an early stage, and primarily serve as progenitors of fibrous root branches, the conduits for water and nutrient transport to the stem, and key storage organs for nonstructural carbohydrates and mineral nutrients.

The propagation technique and grafting affect the biomass distribution between the aboveground (shoot) and belowground (root) plant organs. Seedling nongrafted trees in a 1-year-old plantation produced more aboveground biomass than the other treatments. However, in terms of the root-to-shoot ratio, the clonal trees (grafted and nongrafted) produced a higher rootto-shoot ratio than the seedling trees. According to Wolstenholme (1987), the avocado tree root system is relatively inefficient, with low hydraulic conductivity and few mycorrhizal associations. Therefore, greater root than shoot biomass, as observed in clonal trees, could reduce the potential for water or nutrient stress by allowing for increased water and nutrient absorption and increased new root initiation (C. Fassio, unpublished data; Saura-Mas and Lloret, 2014 ).

In clonal rootstocks, a decreased root and shoot biomass could be due to the clonal propagation method used for avocado trees (Brokaw, 1987), where grafting is performed when new adventitious roots are emerging, thereby presenting a major constraint to the root growth in the early stages of plant development (C. Estay, unpublished data). In the seedling trees, grafting also reduced the root and shoot biomass. Studies with macadamia seedling trees (Firth et al., 2003) showed the same results after tree excavation. It was suggested that, in macadamia trees, root breaks during transplanting from a seedbed to a pot and/or restriction of root growth in the pot before planting could result in shallow root system grafting compared with nongrafted trees. However, in the current study, nursery management was the same for grafted and nongrafted avocado trees, and the main reason for the differences could be attributed to the apical wedge grafting method. In this method, the shoot apex is completely removed so that sap flow, assimilates, and hormone transport are disrupted. Studies by Reed et al. (1998) of arabidopsis
(Arabidopsis thaliana) indicated that the removal of the shoot apex reduced the elongation of the primary root. Decreased root growth over at least 1 month (time required for new shoot growth) resulted in an interruption of taproot apical dominance, inducing an increase in lateral root growth (Lloret and Casero, 2002; Willaume and Pagès, 2006). According to Lloret and Casero (2002), when the root apex is removed, the assimilates are redirected to lateral root development. Research with stone pine (Pinus pinea) showed that assimilated partitioning depends on the time of separation. Removing the taproot tip of young seedlings (with lateral roots in the upper section of the root system) resulted in an immediate assimilate accumulation in the upper section and higher lateral root growth. However, removing the taproot tip in mature seedlings (with lateral roots in the upper, middle, and lower sections of the root system) resulted in the homogeneous redistribution of assimilates along the main root axes (Atzmon et al., 1994). In the current study, a small root system developed at the time of grafting, causing a significant change in the root architecture, which has not been previously reported in avocado seedling rootstocks.

\section{Conclusions}

Clonal trees produced main framework roots with shallower angles than seedlings and more fine roots and increased the root length density. Fertigation is common in the avocado industry. Therefore, shallow root systems with more fine roots developed by clonal rootstocks could provide a more absorptive surface area than deeper root systems developed by seedlings rootstocks. Further field studies are necessary to confirm the possible links between root morphology and water and nutrient uptakes in avocados.

The grafting of both clonal and seedling trees resulted in similar root architecture, revealing that grafting has a significant effect on enhancing the development of more lateral main roots in taprooted plants. Thus, grafting may improve efficiency in the absorption of water and nutrients in these rootstocks, thereby reducing nursery production time. Moreover, 
the planting of nongrafted rootstocks and subsequent grafting (once a deep root system has developed) would be a good alternative when planting in areas with poor soil conditions or with no permanent irrigation.

\section{Literature cited}

Asaah, E.K., T.N. Wanduku, Z. Tchoundjeu, L. Kouodiekong, and P. Van Damme. 2012. Do propagation methods affect the fine root architecture of African plum (Dacryodes edulis)? Trees 26(5):1461-1469.

Atkinson, D. 2000. Root characteristics: Why and what to measure? p. 1-32. In: A.L. Smit, A.G. Bengough, C. Engels, M. Van Noordwijk, S. Pellerin, and S.C. Van De Geijn (eds.). Root methods: A handbook. Springer, New York, NY.

Atzmon, N., O. Reuveni, and J. Riov. 1994. Lateral root formation in pine seedlings. Trees 8(6):273-277.

Brokaw, W. 1987. Avocado clonal rootstock propagation. Proc. Intl. Plant Prop. Soc. 37:97-103.

Charles-Dominique, T., T. Mangenet, $\mathrm{H}$. Rey, C. Jourdan, and C. Edelin. 2009. Architectural analysis of root system of sexually vs. vegetatively propagated yam (Dioscorea rotundata), a tuber monocot. Plant Soil 317(1-2):61-77.

Emmett, B., E.B. Nelson, A. Kessler, and T.L. Bauerle. 2014. Fine-root system development and susceptibility to pathogen colonization. Planta 239(2):325340 .

Firth, D.J., R.D.B. Whalley, and G.G. Johns. 2003. Distribution and density of the root system of macadamia on krasnozem soil and some effects of legume groundcovers on fibrous root density. Austral. J. Expt. Agr. 43(5):503-514.

Frolich, E.F. and R.G. Platt. 1972. Use of the etiolation technique in rooting avocado cuttings. California Avocado Soc. Yrbk. 55:97-109.

Gewin, V. 2010. Food: An underground revolution. Nature 466(7306):552-553.

Gordon, W.S. and R.B. Jackson. 2000. Nutrient concentrations in fine roots. Ecology 81(1):275-280.

Gregory, P.J., C.J. Atkinson, A.G. Bengough, M.A. Else, F. FernándezFernández, R.J. Harrison, and S. Schmidt. 2013. Contributions of roots and rootstocks to sustainable, intensified crop production. J. Expt. Bot. 64(5):1209-1222.

Hartmann, H., D. Kester, F. Davies, and R. Geneve. 2010. Plant propagation:
Principles and practices. 8th ed. Prentice Hall, Upper Saddle River, NJ.

Henry, A., J.C. Rosas, J.S. Beaver, and J.P. Lynch. 2010. Multiple stress response and belowground competition in multilines of common bean (Phaseolus vulgaris L.). Field Crops Res. 117(2-3):209-218.

Ho, M.D., B.C. McCannon, and J.P. Lynch. 2004. Optimization modeling of plant root architecture for water and phosphorus acquisition. J. Theor. Biol. 226(3):331-340.

Hoagland, D. and D. Arnon. 1938. The water-culture method for growing plants without soil. Univ. California, College Agr., Agr. Expt. Sta., Berkeley, CA.

Jackson, R.B., H.A. Mooney, and E.D. Schulze. 1997. A global budget for fine root biomass, surface area, and nutrient contents. Proc. Natl. Acad. Sci. USA 94 (14):7362-7366.

Khuder, H., A. Stokes, F. Danjon, K. Gouskou, and F. Lagane. 2007. Is it possible to manipulate root anchorage in young trees? Plant Soil 294(1-2):87-102.

Kolesnikov, V. 1971. The root system of fruit plants (translated from Russian by $\mathrm{L}$. Aksenova). MIR Publ., Moscow, Russia.

Lloret, P. and P. Casero. 2002. Lateral root initiation, p. 127-155. In: Y. Waisel, A. Eshel, and U. Kafkafi (eds.). Plant roots: The hidden half. Marcel Dekker, New York, NY.

López-Bucio, J., A. Cruz-Ramírez, and L. Herrera-Estrella. 2003. The role of nutrient availability in regulating root architecture. Curr. Opin. Plant Biol. 6 (3):280-287.

Lyford, W. 1980. Development of the root system of northern red oak (Quercus rubra L.). Harvard Univ., Harvard Forest, Petersham, MA.

Lynch, J. 1995. Root architecture and plant productivity. Plant Physiol. 109 (1):7-13.

Maas, E.V. and J.A. Poss. 1989. Salt sensitivity of wheat at various growth stages. Irri. Sci. 10(1):29-40.

Manschadi, A.M., J. Christopher, P. Devoil, and G.L. Hammer. 2006. The role of root architectural traits in adaptation of wheat to water-limited environments. Funct. Plant Biol. 33(9):823-837.

Nepstad, D.C., C.R. de Carvalho, E.A. Davidson, P.H. Jipp, P.A. Lefebvre, G.H. Negreiros, E.D. da Silva, T.A. Stone, S.E. Trumbore, and S. Vieira. 1994. The role of deep roots in the hydrological and carbon cycles of Amazonian forests and pastures. Nature 372(6507):666-669.
Piccotino, D., R. Massai, G. Baroni, and M. Bovo. 1992. Root system conformation and growth of kiwifruit as affected by propagation technique. Acta Hort. 297 (297):391-399.

Picolotto, L., J.C. Fachinello, V.J. Bianchi, R. Manica-Berto, M. da Silveira Pasas, and J. Dutra Schmitz. 2010. Yield and fruit quality of peach scion by using rootstocks propagated by air layering and seed. Scientia Agr. 67(6):646-650.

Polverigiani, S., M.L. McCormack, C.W. Mueller, and D.M. Eissenstat. 2011. Growth and physiology of olive pioneer and fibrous roots exposed to soil moisture deficits. Tree Physiol. 31(11):12281237.

Pregitzer, K.S. 2002. Fine roots of treesA new perspective. New Phytol. 154 (2):267-270.

Reed, R.C., S.R. Brady, and G.K. Muday. 1998. Inhibition of auxin movement from the shoot into the root inhibits lateral root development in Arabidopsis. Plant Physiol. 118(4):1369-1378.

Rubio, G., T. Walk, G. Zhenyang, X. Yan, L. Hong, and J. Lynch. 2001. Root gravitropism and below-ground competition among neighbouring plants: A modelling approach. Ann. Bot. 88 (5):929-940.

Sanguineti, M.C., S. Li, M. Maccaferri, S. Corneti, F. Rotondo, T. Chiari, and R. Tuberosa. 2007. Genetic dissection of seminal root architecture in elite durum wheat germplasm. Ann. Appl. Biol. 151 (3):291-305.

Saura-Mas, S. and F. Lloret. 2014. Adult root structure of mediterranean shrubs: Relationship with post-fire regenerative syndrome. Plant Biol. 16(1):147-154.

Schaffer, B., P.M. Gil, M. Mickelbart, and A. Whiley. 2013. Ecophysiology, p. 168199. In: B. Schaffer, B.N. Wolstenholme, and A.W. Whiley (eds.). The avocado: Botany, production and uses. CAB Intl., Wallingford, UK.

Severino, L.S., R.L.S. Lima, A.M.A. Lucena, M.A.O. Freire, L.R. Sampaio, R. P. Veras, K.A.A.L. Medeiros, V. Sofiatti, and N.H.C. Arriel. 2011. Propagation by stem cuttings and root system structure of Jatropha curcas. Biomass Bioenergy 35(7): 3160-3166.

Sutton, R. and R. Tinus. 1983. Root and root system terminology. Soc. Amer. Foresters, Washington, DC.

Valenzuela-Estrada, L.R., V. VeraCaraballo, L.E. Ruth, and D.M. Eissenstat. 2008. Root anatomy, morphology, and longevity among root orders in 
Vaccinium corymbosum (Ericaceae). Amer. J. Bot. 95(12):1506-1514.

Vinterhalter, D.V. and B.S. Vinterhalter. 1999. Gravitropic response of adventitious roots cultivated in light and darkness on sucrose-free medium. Phyton 39(3): 61-64.

Wilcox, H. 1964. Xylem in roots of Pinus resinosa Ait. in relation to heterorhizy and growth activity, p. 459-478. In: M.H. Zimmerman (ed.). The formation of wood in forest trees. Acad. Press, New York, NY.
Willaume, M. and L. Pagès. 2006. How periodic growth pattern and source/sink relations affect root growth in oak tree seedlings. J. Expt. Bot. 57(4):815-826.

Williams, M., Y. Malhi, A.D. Nobre, E.B. Rastetter, J. Grace, and M.G.P. Pereira. 1998. Seasonal variation in net carbon exchange and evapotranspiration in a Brazilian rain forest: A modelling analysis. Plant Cell Environ. 21(10):953-968.

Wolstenholme, B. 1987. Theoretical and applied aspect of avocado yield as affected by energy budgets and carbon partitioning. South African Avocado Growers' Assn. Yrbk. 10:58-61.

Yamashita, M., T. Takyu, and T. Saba. 1997. Gravitropic reaction in the growth of tea roots. Jpn. J. Crop. Sci. 66(3): $472-478$.

Zeppel, M.J.B., B.R. Murray, C. Barton, and D. Eamus. 2004. Seasonal responses of xylem sap velocity to VPD and solar radiation during drought in a stand of native trees in temperate Australia. Funct. Plant Biol. 31(5):461-470. 